\title{
Einstein, Bergson, and the Experiment that Failed: Intellectual Cooperation at the League of Nations
}

\section{Citation}

Canales, Jimena. 2005. Einstein, Bergson, and the experiment that failed: Intellectual cooperation at the League of Nations. Modern Language Notes 120(5): 1168-1191.

\section{Published Version}

http://dx.doi.org/10.1353/mln.2006.0005

\section{Permanent link}

http://nrs.harvard.edu/urn-3:HUL.InstRepos:3210598

\section{Terms of Use}

This article was downloaded from Harvard University's DASH repository, and is made available under the terms and conditions applicable to Other Posted Material, as set forth at http:// nrs.harvard.edu/urn-3:HUL.InstRepos:dash.current.terms-of-use\#LAA

\section{Share Your Story}

The Harvard community has made this article openly available.

Please share how this access benefits you. Submit a story.

Accessibility 


\title{
Einstein, Bergson, and the Experiment that Failed: Intellectual Cooperation at the League of Nations
}

\author{
Jimena Canales
}

Do not think for a moment that I consider my own fellow countrymen superior and that I misunderstand the others-that would scarcely be consistent with the Theory of Relativity ...

-Albert Einstein to Marie Curie, December 25, 1923

\section{Introduction}

On April 6, 1922, Henri Bergson and Albert Einstein met at the Société française de philosophie in Paris to discuss the meaning of relativity. In the years that followed, the philosopher and the physicist became engaged in a bitter dispute. ${ }^{2}$ It is commonly asserted that during their confrontation Bergson lost to the young physicist; as subsequent commentators have insisted, Bergson made an essential mistake because he did not understand the physics of relativity. ${ }^{3}$ Their debate exemplified the victory of "rationality" against "intuition." It was a key moment which demonstrated that intellectuals (like Bergson) were unable to keep up with revolutions in science. For the physicists Alan Sokal and Jean Bricmont, the "historical origins" of the "Science Wars" lay in Einstein's and Bergson's fateful meeting. Since then, they have seen the malaise of le bergsonisme continuing to spread-recently reaching "Deleuze, after passing through Jankélévitch and Merleau-Ponty." 
Bergson, however, never acknowledged any such defeat. ${ }^{6}$ In his view, it was Einstein and his interlocutors who did not understand him. ${ }^{7}$ He attempted to clarify his views in no less than three appendices to his famous book Durée et Simultanéité, in a separate article "Les temps fictifs et les temps réel" (May 1924), and in a long footnote to La Pensée et le mouvant (1934). Despite these attempts, many of his previous followers abandoned him. Gaston Bachelard, for example, referred to him as the philosopher who had lost against Einstein. But others, like Maurice Merleau-Ponty, persisted in defending him. This small group resigned themselves to being categorized by Einstein's defenders as retrograde, irrational, and ignorant. Among the most important thinkers who have since followed this debate we can list: Gaston Bachelard, Léon Brunschvicg, Gilles Deleuze, Emile Meyerson, Martin Heidegger, Jacques Maritain, Karl Popper, Bertrand Russell, Paul Valéry, and Alfred North Whitehead.

In what follows I will give an account of the Einstein-Bergson debate about science by paying particular attention to its effect on a political debate that occurred at the same time. The context involves an institution founded on the hope that if intellectuals could learn to cooperate then nations might follow: the International Commission for Intellectual Cooperation (CIC) of the League of Nations, a forerunner of UNESCO. Disagreements between Bergson and Einstein plagued the Commission until it was informally dissolved in 1939, in the face of a second world war.

The political views of Bergson and Einstein and the history of scientific internationalism have been amply studied before. ${ }^{8}$ Yet the scientific Bergson-Einstein debate and the political Bergson-Einstein debate, taking place simultaneously, have been considered to be independent from each other. ${ }^{9}$ It is evident, however, that both Bergson and Einstein (as well as those around them) often drew connections between the two. This article explores these connections symmetrically to expose the ways in which boundaries between nature, science, and politics shifted during this period. It is pertinent to study these shifts first to understand the ancillary debates in science and politics that have thus far dominated historiography. ${ }^{10}$

This episode marks an important change in the place of science and philosophy in history. Einstein and Bergson's debate covered much more than the nature of time and simultaneity. At stake in their debate was the status of philosophy vis à vis physics. It was, in essence, a controversy about who could speak for nature and about which of these two disciplines would have the last word. ${ }^{11}$ 


\section{The time in between}

At the time of their debate, Einstein was a growing star in science. Arthur Eddington's 1919 eclipse expedition had brought him international fame. ${ }^{12}$ Partly because of his vocal pacifist and anti-nationalist stance, Einstein was the one German-born scientist to whom many members of the international community gladly turned. He received the Nobel Prize in Physics for 1921.

Bergson's vita was similarly brilliant. At the Lycée Condorcet he had obtained prizes in English, Latin, Greek, and in philosophy. He was acclaimed for his mathematical work, receiving a national prize and publishing in the Annales de mathématiques. He published two theses, one a highly specialized dissertation on Aristotelian philosophy and another one-Essai sur les données immédiates de la consciencewhich would go through countless editions. In 1898, he became a professor at the École Normale; in 1900, he moved to the Collège de France. In 1907, his fifth book, L'Évolution créatrice, brought him universal fame. His lectures at the Collège de France were so crowded with tout Paris, that his students could not find seats. (It was rumored that socialites sent their servants ahead of time to reserve them.) During his reception at the Académie française, he received so many flowers and such applause that underneath the clamor he was heard to protest, "Mais . . . je ne suis pas une danseuse!" Even the Paris Opera, it was evident, was not spacious enough for him. ${ }^{13}$ This universal fame followed him until 1922, when he published Durée et simultanéité, a book which he described in its preface as a "confrontation" with Einsteinian interpretations of time.

During his meeting with Einstein, Bergson said that he "had come here to listen." When he first spoke, he lavished praise on the controversial physicist. The last thing he intended to do was to engage Einstein in a debate. With regard to Einstein's theory Bergson had no objections: "I do not raise any objections against your theory of simultaneity, any more than I do not raise them against the Theory of Relativity in general." 14 All that Bergson wanted to say was that "all did not end" with relativity. He was clear: "All that I want to establish is simply this: once we admit the Theory of Relativity as a physical theory, all is not finished. ${ }^{15}$ Philosophy, he modestly argued, still had a place.

Einstein disagreed. He fought against giving philosophy (and by inference Bergson) any role in matters of time. His objections were based on his views about the role of philosophy in society-views which differed from Bergson's. 


\section{Bergson's error}

The debate between Einstein and Bergson needs to be understood in the context of Bergson's Durée et simultanéité. At the time of their meeting in Paris, the book was in press, containing Bergson's "mistake" with regard to the twin paradox. ${ }^{16}$ According to the Theory of Relativity, two twins, one who traveled outside the earth at a speed close to that of the speed of light and the other one who remained on earth, would meet each other and notice that time had elapsed differently for each of them. Their clocks and calendars would show disagreeing times and dates. The twin who had stayed on earth would have aged more rapidly; time would have slowed down for the one who had traveled.

In his controversial book, Bergson denied this to be the case. He categorically stated that the clock of the traveling twin "does not present a retardation when it finds the real clock, upon its return." ${ }^{17}$ Critics since then have often cited Bergson's remark that "once reentering, it marks the same time as the other" as proof of his profound misunderstandings of relativity. ${ }^{18}$ This single statement was enough to discredit him in the eyes of most scientists—and it remains so to this day.

Bergson's controversial statement was part of a much larger argument that has been forgotten. In fact, Bergson did acknowledge that the twins' times would differ under most circumstances. His statement only held true under quite special circumstances-circumstances that did not allow for any differences in the twins' situations, not even differences in acceleration. Explicitly focusing only on movement which was "straight and uniform," he demanded that "[t]heir situations be identical."19 In every other case, Bergson accepted that the twins' clock-times would differ.

In the first appendix to the second edition of his book, Bergson expressed his irritation against readers who overlooked this aspect of his argument and who claimed that he denied the retardation of the traveling clock. He tried to prove them wrong by clearly stating his belief in the theory's physical effects on time: "We have already said it, and cannot cease to repeat it: in the Theory of Relativity the slowingdown of clocks by their displacement is, rightfully, as real as the shrinkage of objects in terms of distance. ${ }^{\prime 0}$ But few listened.

Since then, Bergson has been frequently considered to have held scientific facts in disdain. Yet even in the preface to the first edition of Durée et simultanéité, he showed every possible respect for the facts of 
observation: ". . . we take the formulas of Lorentz, term by term, and we find out to which concrete reality, to what thing perceived or perceptible, each term corresponds." ${ }^{11}$ Bergson, who knew Hendrik Lorentz and Albert I. Michelson personally and deeply admired them, wanted more not less weight placed on Lorentz's formulas and on the results of the Michelson-Morley experiment. ${ }^{22}$ He complained that "The Theory of Relativity is not precisely based on the Michelson and Morley experiment." 23 Einstein, in contrast, showed a surprisingly cavalier lack of concern for its experimental results. ${ }^{24}$

\section{The Neo-Platonist objection}

Bergson applied an objection to Einsteinian relativity that had once been brought up by the Cambridge philosopher Henry More in the seventeenth century, against Descartes' theory of relative motion. ${ }^{25}$ Using the example of a ship leaving its dock, Descartes claimed that there was no way of distinguishing absolute from relative motion. Henry More objected, in the same way Bergson would later object to Einstein, that a certain difference would always remain between the two motions. More reminded Descartes that if one person was at rest (seated) and the other in motion (running), their differences could be clearly determined because the person doing the running would be flushed.

Einstein insisted on the relativity of each twin's time. For Bergson, in contrast, acceleration was tantamount to being flushed from running, in analogy with More's example. It was an inescapable mark of a difference in the twins' situations. Since $a$ difference existed, one that resulted in a difference in times, then their times were not equal in every respect. Essential differences, for example, could remain in terms of memory or in a sense of effort.

Differences in clock times, which arose in connection with differences in acceleration, proved that something was different between the twins' experiences of time. Acceleration created a dissymmetry, which in turn proved that the twins' times were not equal in every sense: "So, if one wants to deal with Real Times then acceleration should not create a dissymmetry, and if one wants for the acceleration of one of these two systems to effectively create a dissymmetry between them, then we are no longer dealing with Real Times." ${ }^{26}$ Even physicists at the time would have had to agree with his principal assertion: an acceleration would be necessary for the traveling twin to change directions and return to earth to compare his time. Under 
these circumstances the two experiences of time cannot thus be said to be entirely identical.

Bergson disagreed with Einstein about what would happen once the twins met back on earth. The philosopher André Lalande, who wrote about the debate, explained: "The chief question here, of course, is to know what sort of reality should be accorded to the various opposed observers who disagree in their measurement of time." ${ }^{27}$ Although physically the twins' times were equally valid, Bergson argued that philosophically differences could remain between them. Whose time would prevail back on earth would depend on how their disagreement was negotiated-not only scientifically, but psychologically, socially, politically, and philosophically. More's ironic thesis became for Bergson a seventeenth-century version of the twin paradox. It encapsulated Bergson's main point: that philosophy had the right to explore the differences in time and distance that relativity had shown varied amongst observers.

\section{The time of their lives}

After meeting for the first time in Paris, Bergson and Einstein were scheduled to meet again in a few months, this time, for an entirely different purpose. Bergson was president of the CIC and Einstein had been named as one of its members. Bergson was well aware that the power of the CIC depended on the strength of its members. ${ }^{28}$ While the participation of both men already augmented its prestige, the excitement around it only intensified after their heated encounter in Paris. The fate of the commission was now colored by the BergsonEinstein debate. For its participants, it was at least as important as the meeting itself.

Bergson's choice for the presidency of the CIC was obvious, since he was the single most politically committed intellectual of his time. In 1916 he had gone to Spain on a diplomatic mission with the hope of securing an alliance between the Spanish government and the Allied powers. The next year he played an essential role in convincing American president Woodrow Wilson to enter the war against Germany. His reputation as a mender of intellectual schisms was established during his tenure as president of the Académie des sciences morales et politiques. At the start of the Great War, a group of members of the Institut de France demanded the expulsion of foreign associates of German nationality. ${ }^{29}$ The philosophers of the Institut, as a group, condemned this initiative. Bergson was responsible 
for drafting a declaration that condemned the war but did not go to the extreme of expulsing German nationals. ${ }^{30}$

Einstein was also well aware of how politics affected science. He, for example, boycotted the Solvay Congresses that were resumed after the war in order to protest the exclusion of German scientists from international scientific forums. ${ }^{31} \mathrm{He}$ knew that his internationalist stance made him popular with some, unpopular with others. During those years he became deeply concerned with expanding the relevance of his Theory of Relativity beyond the community of physicists. In 1916, he published a "gemeinverständlich" version of both the Special and General Theory. His catapult to fame because of Eddington's eclipse expedition soon dwarfed these early popularization attempts. Popular expositions of relativity proliferated almost automatically after this date. His Über die spezielle un die allgemeine Relativitätstheorie (gemeinverständlich) was translated into English, French, Spanish and Italian. Then came his famous Four Lectures on Relativity, presented at Princeton University in 1921.

His newfound fame carried strong political connotations, representing the triumph of internationalist (Allied) science over base nationalist (German) passions. Almost immediately after he joined the CIC in 1922, Einstein thought of resigning because of the prevailing anti-German sentiments of many of its members. ${ }^{32} \mathrm{He}$ did not feel he could "truly represent the intellectual milieu and the Universities of Germany" because of his "condition as Israelite, on the one hand, and on the other because of his anti-chauvinistic feelings from the German point of view." 33 Marie Curie and others pleaded with him, and he chose to remain. But his support for the CIC remained so lukewarm that he missed its first meeting. ${ }^{34}$ Soon thereafter, he resigned in earnest, publishing a sharply worded statement against it.

Einstein accused the CIC of being "even worse" than the League of Nations and of appointing "members whom it knew stand for tendencies the very reverse of those they were bound in duty to advance." ${ }^{35}$ His highly public resignation only made the work of these institutions more difficult. His behavior appeared paradoxical to many of his colleagues. ${ }^{36}$ How could a scientist who preached about internationalism refuse to take place in these outreach activities? After all, he was being invited (they had indeed pleaded) as a German-born member. Had not Einstein repeatedly protested the exclusion of German scientists?

During this tumultuous period Einstein continued to frame his 
Theory of Relativity and his debate with Bergson symmetrically, in both political and scientific terms. In a letter to his friend Maurice Solovine, he connected his decision to resign from the CIC to Bergson's reception of relativity:

I resigned from a commission of the League of Nations, for I no longer have any confidence in this institution. That provoked some animosity, but I am glad that I did it. One must shy away from deceptive undertakings, even when they bear a high-sounding name. Bergson, in his book on the Theory of Relativity, made some serious blunders; may God forgive him. ${ }^{37}$

Forced on other occasions to explain his decision to resign while combating views that he was being pro-German, he again stated that his position with regard to the CIC was consistent with the Theory of Relativity. In a letter to Marie Curie written in December of 1923, he explained: "Do not think for a moment that I consider my own fellow countrymen superior and that I misunderstand the others-that would scarcely be consistent with the Theory of Relativity." ${ }^{38}$ Relativity, in those years, went far beyond his famous 1905 and 1915 papers. To Einstein and to those who followed his relationship with Bergson and the CIC, it encapsulated distinct political and ethical views. With his growing international fame Einstein started to become more than a physicist. He obtained a role that would remain with him up to this day, that of a physicist-philosopher, with vocal political opinions.

\section{Paris against time}

Einstein's transformation into a philosopher, at least in Paris, occurred in the context of political tensions between France and Germany and of differences within the communities of philosophers and physicists. ${ }^{39}$ His visit was highly symbolic for the two countries. ${ }^{40}$ After receiving three invitations in 1922 (the last one from the Collège de France), Einstein declined all of them. He had, however, second thoughts about the last one. These doubts intensified after a conversation with the foreign minister, Walther Rathenau, who worked to improve relations between the two nations, and who urged him to accept. Shortly thereafter he withdrew his declination, notified the Prussian Academy of Sciences, and began to prepare his trip. ${ }^{41}$

Einstein explicitly stated why philosophy should not play a role at all with respect to time. During the debate with Bergson, he explained how time could be understood either psychologically or physically, but not philosophically. The philosopher's time, he insisted, 
did not exist: "the time of the philosophers does not exist, there remains only a psychological time that differs from the physicist's." ${ }^{4}$ This view was based on a very particular and extremely narrow conception of philosophy: philosophy should explore the overlap between psychology and physics: "The time of the philosopher, I believe, is a psychological and physical time at the same time." ${ }^{43}$ It was also based on a quite precise and equally narrow view of psychological conceptions of time. These, he insisted, did not exist in reality: "These are nothing more than mental constructs, logical entities." With these strict definitions of physics and psychology, Einstein claimed that no overlap existed between psychological conceptions and physical conceptions of time. He, therefore, did not see a role for philosophy in matters of time.

Bergson gladly granted that psychological conceptions of time differed from physical ones. Knowledge of this, he bemoaned, was hardly new. Henri Piéron, an experimental psychologist, joined the debate by reminding listeners of the problem of the personal equation that arose in astronomical determinations of time: "For a long time now, astronomers have known that it is impossible to base precise determinations of physical simultaneity on psychological simultaneity. . . ."45 This example clearly illustrated the difference between psychological and physical conceptions of time. ${ }^{46}$ If the enormous speed of light had caused this realization to arrive slowly for physicists, the slow speed of nerve transmission had made it evident a long time ago for physiologists, psychologists, and astronomers. They had long known that perceptions of simultaneity differed from physical simultaneity. Legend had it that most scientists had learned this lesson as early as 1795 . Relativity, in this respect, had only rediscovered what had already been known.

Bergson reacted against a perceived encroachment of physics on philosophy. ${ }^{47}$ In the preface to the first edition of Durée et simultanéité he stated his motivation for pursuing a confrontation. It arose from a "devoir," that hinged on defending the place of philosophy vis-à-vis science: "The idea that science and philosophy are different disciplines meant to complement each other... arouses the desire and also imposes on us the duty to proceed to a confrontation." 48 On numerous occasions he took pains to stress that he held no grudge against Einstein as an individual and had no qualms against the physical nature of Einstein's theory. He thus differentiated his position from the racist and nationalist attacks that Einstein encountered in Germany. He objected only to certain philosophical extensions of relativity, uses which, he 
claimed, arose from a confusion prevalent "in those who transform this physics, telle quelle, into philosophy." 49

While both Bergson and Einstein accepted that an essential difference existed between psychological and physical conceptions of time, they both drew different conclusions. For Bergson, this difference only made the philosopher's task more interesting and more relevant, especially because no one, not even physicists, could avoid the problem of relating time back to psychology. Every time humans "read an instrument," psychological riddles reappeared. Piéron agreed with Bergson: the schism between psychological and physical determinations of time, revealed by the problem of the personal equation, did not invalidate the philosopher's time, "Therefore Bergsonian duration seems to me to remain a stranger to physical time in general and particularly to Einsteinian time." ${ }^{50}$ Einstein, however, never accepted this division of labor.

\section{Timely attacks}

Bergson temporarily had the last word during their meeting at Société française de philosophie. His intervention negatively affected Einstein's Nobel Prize, which was given "for his services to theoretical physics, and especially for his discovery of the law of the photoelectric effect" and not for relativity. The reasons behind this decision, as stated in the prize's presentation speech, were related to Bergson's intervention: "Most discussion [of Einstein's work] centers on his Theory of Relativity. This pertains to epistemology and has therefore been the subject of lively debate in philosophical circles. It will be no secret that the famous philosopher Bergson in Paris has challenged this theory, while other philosophers have acclaimed it wholeheartedly." ${ }^{51}$ For a moment, their debate dragged matters of time out of the solid terrain of "matters of fact" and into the shaky ground of "matters of concern." "52

But Einstein and his followers in Paris did not permit the philosopher's confrontation to pass so lightly. Within Paris, divisions between physicists and philosophers colored Einstein's reception. He was embraced by the Collège de France (particularly by Paul Langevin, who had invited him), greeted at the border by an astronomer from the Paris Observatory (Charles Nordmann met Einstein along with Langevin), courted by the Société de Philosophie (in whose forum he debated with Bergson), admired at the Société astronomique de France (especially by its president, the prince Bonaparte), and 
welcomed by the Société de Chimie Physique. The Société française de Physique, ironically, rejected him completely. ${ }^{53}$

Jean Becquerel, the son of the eminent physicist Henri Becquerel, defended Einstein and attacked Bergson. Becquerel was the first physicist after Langevin to introduce classes on relativity at the École polytechnique and at the Muséum d'Histoire Naturelle, where he was a professor. He published two books on relativity in 1922, one of them designed for a general audience. In an article published in the Bulletin scientifique des Etudiants de Paris, he took up the fight against le bergsonisme..$^{54}$ Becquerel insisted that objections against Einstein's theory resulted from misunderstandings and erroneous reasoning. ${ }^{55}$

This attack was followed by one in a book by André Metz, a military man and alumnus of the École polytechnique, who in 1923 published yet another book on relativity. ${ }^{56}$ In it he again attacked the philosopher, who he claimed was guilty of having transformed a beautiful "child" into a "monster." ${ }^{57}$ Bergson replied to these objections in a new preface and three appendices to the second edition of Durée et simultanéité..$^{58}$ These appendixes, however, only intensified the debate between him and the physicists. In 1924 Metz wrote a direct response to Bergson's new works. ${ }^{59}$

Bergson responded once again to Metz in an article entitled "Les temps fictifs et les temps réels" (May 1924) in which he again tried to defend his philosophy. ${ }^{60} \mathrm{He}$ countered Metz's claim that he was professing a theory of relativity that differed from Einstein's. All he was doing, he insisted, was philosophy—not physics, and these two disciplines were different: "Toute autre est le rôle du philosophe." ${ }^{\prime 1}$ Metz's claim that physicists had a "special competence" with respect to questions of time and relativity was therefore inapplicable. And physicists, he added, were rarely philosophically competent: “. . . one can be an eminent physicist and not be trained to the handling of philosophical ideas ... it is in vain that one argues here their special competence: the question no longer belongs to physics." He chastised Relativity theory for its desire to "stop being a physics to become a philosophy." ${ }^{2}$ Bergson felt that questions of authority were being brought up gratuitously. Reacting against a perceived growth in the authority of physicists, he concluded: "Besides, whether we are dealing here with physics or philosophy, the recourse to authority has no value. ${ }^{33}$ Ultimately, he accused Metz of not having understood him. ${ }^{64}$

Metz was not alone in ignoring Bergson's insistence that he was doing philosophy—not physics. This strategy was, in fact, due to 
Einstein. In a private letter to Metz, he echoed the judgment made previously to Solovine with regard to Bergson's mistake. This time he wrote: "It is regrettable that Bergson should be so thoroughly mistaken, and his error is really of a purely physical nature, apart from any disagreement between philosophical schools." He spelled-out Bergson's mistake in detail: "Bergson forgets that the simultaneity ... of two events which affect one and the same being is something absolute, independent of the system chosen." ${ }^{\circ 5}$ The director of the prestigious Revue de philosophie did not hesitate to publish Einstein's response. ${ }^{66}$

The letter Einstein sent to Metz arguing that Bergson's error was due to his misunderstanding of physics was not the only one sent and not the only one subsequently published. At least one other reached Miguel Masriera Rubio, a professor of physical chemistry in Barcelona. Masriera Rubio became Einstein's defender and Bergson's attacker in the Spanish speaking world. ${ }^{67} \mathrm{In}$ articles published in the prestigious Vanguardia newspaper, he brought the debate to the public. Like Metz, Masriera Rubio decided to publish a letter from Einstein that contained the following damning sentence: "In short, Bergson forgets that spacetime coincidences have an absolute character according to the Theory of Relativity." 68 With these two letters and their dissemination, Einstein effectively ended the controversy in his favor.

Why, despite Bergson's repeated claims that he fully accepted the physics of relativity, and that he was only doing philosophy, did Einstein (through Metz, Masriera Rubio and others) insist on Bergson's incompetence as a physicist? Bergson speculated that the reason was that Einstein simply did not understand him. In a letter to Lorentz, he explained:

In general, relativity physicists have misunderstood me. They, by the way, frequently do not know my views except than through hearsay, by inexact and even completely false accounts. This is perhaps the case of Einstein himself, if what they say about him is true..$^{69}$

Framing the terms of the debate in terms of physics had two consequences. First, it denied Bergsonian philosophy the right to mark its independence from physics. Secondly, it assigned to physicists a "special competence" with respect to these questions.

In the end, Bergson and Einstein's debate could be summarized as a disagreement about how one should deal with disagreement. This included the disagreement about time coordination, as in the example of the twins, but included other issues. Should one deal with 
disagreement as a physicist or as a philosopher? Through negotiation or by fiat? As an expert or as a commoner? These questions were all pertinent at the CIC, where both Bergson and Einstein were trying hard to work for peace.

Discussions of time were particularly relevant for the CIC for one essential reason. Its organization was modeled after previous scientific international commissions created for global sciences (such as geodesy and meteorology), global industries (such as electric, telegraphic, and rail), and global standards (time, longitudes, weights, and measures). ${ }^{70}$ In these forums physicists, astronomers, and even engineers waxed philosophical, pondering, in universal terms, about the nature of science, consensus and truth. The famous scientist Henri Poincaré, for example, developed his philosophy of conventionalism in the context of international debates about the standardization of time and longitude. His position contrasted with that of Einstein, who never worked through the long, painful negotiations necessary for reaching an agreement on time standardization. ${ }^{11}$

Perhaps Bergson was pessimistic. He, after all, had seen France, Germany, and Britain engaged in a bitter debate about which country's time and time keeping methods would prevail. Would not the twins, in the famous paradox, have to do the same in order to live together on earth, peacefully?

\section{The CIC experiment}

The debate between Einstein, Metz, and Bergson appeared in the July 1924 issue of the Revue de philosophie. That summer was colored by an equally painful debate at the CIC. Should Einstein be asked to rejoin, even after he had sent to the press insulting remarks about the League of Nations? The question of reintegrating Einstein into the CIC resulted in part from the pressure of the British, who sought to profit from the diplomatic isolationalism that France's occupation of the Ruhr area had brought on, and the concurrent devaluation of the franc. Gilbert Murray (CIC member, scholar of ancient Greek literature, and world peace advocate) was afraid that without Einstein "this Committee, like all the organizations of the League of Nations, is in danger of having the Latin element overrepresented. ..." ${ }^{\text {2 }}$ In a letter marked "confidential" he pleaded and offered a carefully worded statement aimed at combating public criticisms: "There would be no inconsistency in this. You resigned as a protest after the invasion of the Ruhr [on March 1923] and the subsequent embitterment of 
feeling between France and Germany, and your return to the Committee would mark the beginning of that rapprochement to which we are all looking forward." ${ }^{73}$ Einstein accepted the offer and espoused the official explanation. ${ }^{74}$

For the meeting proper (July 25, 1924) Bergson reintroduced him with a flattering tribute, but during the meeting break their differences once again became evident. ${ }^{75}$ The philosopher Isaak Benrubi, who decided to attend the CIC's meeting in Geneva only after learning that both Einstein and Bergson would attend, approached Einstein to ask him what he thought of Durée et simultanéitée ${ }^{76}$ Einstein offered his official response, that Bergson had not understood the physics of relativity; that he had made a mistake. ${ }^{77}$ Asked if he would continue the fight against Bergson, Einstein responded: "No, I do not intend to do that, unless Bergson himself provokes a polemic. But that would not help anybody." Einstein was willing to let bygones be bygones: "Time will pass and then we can judge with more objectivity."78

Einstein and Bergson did not learn to work together at the CIC. Passions flared again when the French government offered the CIC the option of building an International Institute for Intellectual Cooperation (IIIC) in Paris. Einstein (and others) expressed his concern that the CIC was international only nominally, and in effect nationalistically French. Bergson tried to calm his fears, promising that the institute would remain "rigorously and completely international." 79 He could not turn down the government's generous offer. When he accepted, Einstein became more and more suspicious of the CIC's underhand nationalism. He did not attend the next meeting, which was held in Paris, instead of in Geneva. ${ }^{80}$

While Einstein was suspicious of the CIC's "internationalism," others were suspicious of Einstein's, particularly in light of his increasing role as a Zionist. Was it not contradictory, they asked, that Einstein was fighting for the establishment of Israel, while he was preaching about internationalism? For years Einstein maintained that these two endeavors were not contradictory: "my Zionism does not preclude cosmopolitan conceptions. ..." ${ }^{\prime 1}$ Bergson's response to antiSemitism and the growing horrors of Nazism would be very different from Einstein's. His national affiliation always remained firmly French. Einstein invited Bergson to participate in the inauguration of the Hebrew University of Jerusalem. Bergson declined in February 1925 saying he was too busy, and quickly changed the topic back to Einstein's participation at the CIC. ${ }^{82}$

In August 1925, Einstein once again criticized the CIC for its 
double face, and Bergson resigned, citing an illness. ${ }^{83}$ Bergson's resignation from the CIC marked the end of his political involvement. After this date he completely retired from public life. The influence of the French intelligentsia in world affairs decreased in direct proportion to the decline in the health and prestige of its main proponent, Bergson.

In 1929 Paul Valéry took Einstein, who was passing through Paris, to visit a very sick and recently operated upon Bergson at his bedside. ${ }^{84}$ A few years later, when the poet received his copy of Bergson's last book La Pensée et le mouvant (1934), he was particularly intrigued by a long footnote "on the subject of the grande affaire of Relativity." Referring to the recent advances in quantum mechanics which Einstein famously resisted, he asked if these "up-to-date microphysics" could be brought to bear on "some of your conceptions?" Perhaps only a poet could hope for either reconciliation or for the comeback of le bergsonisme.

Bergson dedicated the last years of his life to writing his last works, including Les Deux sources de la morale et de la religion (1932), a book whose pessimistic tone regarding war, peace and cooperation, was influenced by his own experience at the CIC. The failure of the League of Nations was not due to its powerlessness, to its lack of a means of enforcement, as many believed: "Even if the League of Nations would take an armed form sufficient in its appearance ... it would collide with the profound war instinct which covers civilization." ${ }^{86}$ Its troubles ran much deeper. Einstein did not increase his attendance. From 1926-30 he attended only three meetings. ${ }^{87}$ The CIC lost momentum and its final session took place in July 1939. ${ }^{88}$

Bergson's and Einstein's hopes for the CIC ended along with their debate. Its unraveling was as immediate as solutions were evident. A few days before the last meeting Gilbert Murray wrote to Einstein in a desperate attempt to solve the institution's woes: "The best solution of all these difficulties is obvious! It is that you should remain with us, but perhaps that is too much to hope for." ${ }^{\text {89 }}$ During the years that followed, the debate's participants suffered the consequences of a worsening political situation. By 1933 Einstein had moved to Princeton and abandoned his pacifism. Less than a month after the last meeting of the CIC, he started advocating atomic bomb research. Metz's home was searched by the Germans who stole his correspondence with Einstein and who took the rest of his belongings. He immigrated to London joining Charles de Gaulle's Free France resistance movement. ${ }^{90}$ With Franco's rise to power, Masriera Rubio also went into exile. 
Bergson's response to Nazism was very different. After the fall of France to Nazi Germany in June 1940, he did not ask the German or Vichy government for special treatment. Renouncing all privileges he decided to wait his turn in line in the street and register with other French Jews, in the inclement December weather. He died on January 3,1941 .

\section{"Poetry" between "physics" and "philosophy"}

Bergson received the 1927 Nobel Prize for Literature. ${ }^{91}$ This recognition, he thought, was due to "sympathy," and not towards him, but towards France: "I recognize [the Nobel Prize's] value even more, and I am even more moved by it, when I consider that this distinction, given to a French writer, may be regarded as a sign of sympathy given to France." ${ }^{92}$ Bergson did not-ever-write literature. This apparently minor detail was not grounds for denying him the prize. The organizers went further, treating him "as stylist and as poet." During the award ceremony, Bergson's contributions were framed as aesthetic and literary: "In the account, so far definitive, of his doctrine, L'Évolution créatrice, the master has created a poem of striking grandeur, a cosmogony of great scope and unflagging power, without sacrificing a strictly scientific terminology . . . one always derives from it, without any difficulty, a strong aesthetic impression. . . . The poem, if one looks at it this way, presents a sort of drama." 93

In 1949, the Library of Living Philosophers dedicated a volume to Einstein with the subtitle "Philosopher-Scientist", cementing new relations between science, physics and philosophy. ${ }^{94}$ If political events during the early decades of the twentieth century conspired to turn Bergson into a poet-philosopher, by the middle of the century Einstein had been transformed into a physicist-philosopher.

Harvard University

\section{NOTES}

A different version of this article was presented at The History of International Scientific Collaboration, International Congress for the History of Science, Beijing, June 24-30, 2005. All translations are by Jimena Canales. The author wishes to thank Lorraine Daston, Elie During, Peter Galison, Suzanne Guerlac, Orit Halpern, David Kaiser, Jean-Marc Lévy-Leblond, Sam Schweber, and Nasser Zakariya for their help and encouragement.

1 Einstein to Curie, Document No. 34 803, 3pp. on p. 3, Folder 9, Folders 34.9-11 League of Nations, Box 14, Einstein Archives. Hereafter designated as EA. 
Einstein's letter was reprinted in Albert Einstein: eine dokumentarische Biographie, ed. Carl Seelig (Zürich: Europa Verlag, 1954) 209-10; and Einstein on Peace, ed. Otto Nathan and Heinz Norden (New York: Avenel, 1960) 64-65.

2 The meeting was recounted in the Bulletin de la Société française de philosophie, 22.3 (July 1922): 102-113. It was reprinted in Bergson, Ecrits et Paroles, 3 vols. (Paris: Presses Universitaires de France, 1959), vol. 3, 497-503; and in "Discussion avec Einstein,” in Mélanges (Paris: Presses Universitaires de France, 1972).

3 The main work proposing that Bergson did not sufficiently understand the physics of relativity is The Bergsonian Heritage, ed. Thomas Hanna (New York: Columbia UP, 1962) 23. Other notable authors who share this view include A. d'Abro, Olivier Costa de Beauregard, and Ilya Prigogine. For a reassessment of Bergson's mistake in light of recent physics see Milič Capek, "What is Living and What is Dead in the Bergsonian Critique of Relativity," in The New Aspects of Time, ed. Robert S. Cohen (Dordrecht: Kluwer, 1991).

4 Two important works written under this point of view are: Bertrand Russell in Mysticism and Logic (Garden City, N.Y.: Doubleday and Co., Inc., 1957) 16; and A.O. Lovejoy, The Reason, the Understanding, and Time (Baltimore: Johns Hopkins UP, 1961) 68 .

5 Alan Sokal and Jean Bricmont, "Un regard sur l'histoire des rapports entre science et philosophie: Bergson et ses successeurs," in Impostures intellectuelles (Paris: Odile Jacob, 1997) 166.

6 The fact that Bergson did not authorize the republication of Durée et simultanéité after 1931 is frequently (and erroneously) taken as an admission of defeat. For details about its exclusion from Bergson's collected works see Édouard Le Roy, "Lettre-préface," in Ecrits et paroles, vol. 1, vii-viii.

7 Bergson explained how "the book has been frequently misunderstood" in "La Pensée et le mouvant," in Oeuvres (Paris: Presses Universitaires de France, 1991 (1934)) $128 \ln 1$.

8 For Einstein's early political views see Thomas Levenson, Einstein in Berlin (New York: Bantam 2003), especially p. 303; and Hubert Goenner, Einstein in Berlin, 1914-1933 (Munich: C. H. Beck, 2005) 291-95. For Bergson's politics in relation to his philosophy the classic account is Philippe Soulez, Bergson politique (Paris: Presses Universitaires de France, 1989).

9 This is the position taken in Rose-Marie Mossé-Bastide, Bergson éducateur (Paris: Presses Universitaires de France, 1955) 122.

10 The main shift in point is the reworking of the division between human and nonhuman time by Bergson and Einstein and its subsequent impact on both science and politics. This change is an important subset of the broad divisions between man and animal and human and non-human studied by Giorgio Agamben: "It is more urgent to work on these divisions, to ask in what way-within man-has man been separated from non-man, and the animal and the human, that it is to take positions on great issues, on so-called human rights and values." Giorgio Agamben, "Mysterium disiunctionis," in The Open: Man and Animal (Stanford: Stanford UP, 2004) 16. For a critique of the asymmetrical treatment of the categories of "science" and "society" by the Sociology of Scientific Knowledge, see Bruno Latour, Politics of Nature: How to Bring the Sciences into Democracy (Cambridge: Harvard UP, 2004); and We Have Never Been Modern (Cambridge: Harvard UP, 1991), especially pp. 39-46.

11 Instead of considering their debate as a delimited case of "endogenous critical inquiry," I focus on the productive excesses of "shop-talk" that cannot be contained within laboratory contexts. On "endogenous critical inquiry," see 
Michael Lynch, "Technical Work and Critical Inquiry: Investigations in a Scientific Laboratory," Social Studies of Science 12 (1982).

12 Matthew Stanley, "An Expedition to Heal the Wounds of War: 1919 Eclipse and Eddington as Quaker Adventurer," Isis 94 (2003).

13 These biographical details are mostly from Bergson and the Evolution of Physics, ed. P.A.Y. Gunter (Knoxville: U Tennessee P, 1969) 3-42.

14 Bergson, "Discussion avec Einstein" 1345.

15 Ibid.

16 For details on the date of its appearance see "Notes des éditeurs," in Mélanges 1600.

17 Appendix III, "Durée et simultanéité: a propos de la théorie d'Einstein," in Mélanges 238.

18 Sokal and Bricmont, "Un regard sur l'histoire des rapports entre science et philosophie: Bergson et ses successeurs" 176.

19 Bergson, "Durée et simultanéité" 128.

20 Bergson, "Durée et simultanéité" 216, italics mine.

21 Bergson, Preface to the First Edition, "Durée et simultanéité" 59.

22 For his meeting and impression of Michelson see Bergson to Xavier Léon, Paris, 8 May 1921 in Henri Bergson, Correspondances, ed. André Robinet (Paris: Presses Universitaires de France, 2002) 934.

23 Bergson, "Durée et simultanéité" 63.

24 The classic work advancing this thesis is Gerald Holton, "Einstein, Michelson, and the 'Crucial' Experiment," Isis 60 (Summer 1969): 133-297.

25 See René Descartes, Les principes de la philosophie, vol. 2, and Henry Morus, Scripta Philosophica, vol. 2.

26 Bergson, "Les Temps fictifs et le temps réel," in Mélanges 1444.

27 André Lalande, "Philosophy in France, 1922-1923," The Philosophical Review 33.6 (1924): 543.

28 Jean-Jacques Renoliet, L'UNESCO oubliée: La Société des Nations et la coopération intellectuelle (1919-1946) (Paris: Publications de la Sorbonne, 1999) 31.

29 For the banning of Germans from various international unions after the war see Kevles, "Into Hostile Political Camps': The Reorganization of International Science in World War I." In 1926 the International Research Council (IRC) decided to stop the exclusion and invited German scientists to join as members. The Germans, however, declined.

30 This incident is described in Bergson, Mélanges, 1104; and Angelo Genovesi, "Henry Bergson: Lettere a Einstein," Filosofia 49.1 (1998): 12n2.

31 He decided to resume attending the Solvay Congresses in April 1926.

32 Germany did not initially belong to the League of Nations, which had been created in Paris in the aftermath of the April 18, 1919 Peace Conference to regulate disputes amongst nations. Germany joined in 1926 after Locarno (1925). Einstein's claim that they were excluding all Germans provoked Lorentz to write a letter (on September 15, 1923) explaining to him that it was not true that German scientists were excluded on principle. On Einstein's vacillations about his membership see Nathan and Norden, Einstein on Peace 59.

33 Cited in Renoliet, L'UNESCO oubliée: La Société des Nations et la coopération intellectuelle (1919-1946) 27. 
34 For Einstein's absence from the September 13, 1922 meeting see "Commission Internationale de Coopération Intellectuelle," in Mélanges 1353.

35 Einstein to Albert Dufour-Feronce (from the German Foreign Office), 1923, 3pp., Document No. 34 877, in Folder 10, Folders 34.9-11 League of Nations, Box 14, EA. Published in Albert Einstein, Mein Weltbild (Amsterdam: Querido, 1934); and Ideas and Opinions (New York: Three Rivers, 1984) 85.

36 See, for example, the reaction of his colleague Max Born: "The papers report that you have turned your back on the League of Nations. I would like to know if this is true. It is, indeed, almost impossible to arrive at any rational opinion about political matters, as the truth is systematically being distorted during wartime." Born to Einstein, Göttingen, April 7, 1923, in The Born-Einstein Letters: Friendship, Politics and Physics in Uncertain Times (New York: Macmillan, 2005).

37 Einstein to Solovine, Pentecost 1923 (May 20, 1923) in Albert Einstein, Letters to Solovine (New York: Philosophical Library, 1987) 59. The original reads: "Bergson hat in seinem Buch über Rel. Theorie schwere Böcke geschossen.” The last sentence of the letter is cited as "God forgive him" in Abraham Pais, Einstein Lived Here (Oxford: Clarendon Press, 1994) 75.

38 The letter appears in Seelig, Albert Einstein: eine dokumentarische Biographie 210. It is also cited in Nathan and Norden, Einstein on Peace 64-65.

39 See Bernadette Besaude-Vincent, "When a Physicist turns on Philosophy: Paul Langevin (1911-39)," Journal of the History of Ideas 49.2 (1988).

40 On this topic see Michel Biezunski, Einstein à Paris: Le Temps n'est plus . . . (Vincennes: Presses Universitaires de Vincennes, 1991).

41 Rathenau was assassinated on June 24, 1922. For details on Einstein's decision to go to Paris, see Nathan and Norden, Einstein on Peace 42-54.

42 Bergson, "Discussion avec Einstein" 1346.

43 Ibid. 1345.

44 Ibid. 1346.

45 Ibid. 1346.

46 For work on the personal equation, see Jimena Canales, "Exit the Frog, Enter the Human: Physiology and Experimental Psychology in Nineteenth-Century Astronomy," British Journal for the History of Science 34 (June 2001); Jimena Canales, "Photogenic Venus: The 'Cinematographic Turn' and Its Alternatives in Nineteenth-Century France," Isis 93 (2002); and Simon Schaffer, "Astronomers Mark Time: Discipline and the Personal Equation," Science in Context 2 (1988).

47 For Bergson's view of the relation of science to philosophy in comparison with Léon Brunschvicg see Frédéric Worms, "Entre critique et métaphysique: la science chez Bergson et Brunschvicg," in Les Philosophes et la science, ed. Pierre Wagner (Paris: Gallimard, 2002).

48 Bergson, "Préface to Durée et Simultanéité," in Mélanges 59, italics mine.

49 Ibid. 60.

50 Bergson, "Discussion avec Einstein" 1346.

51 Arrhenius, 10 December 1922 in Nobel Lectures in Physics (New York: Elsevier, 1967) 1901-21. Cited in Pais, Einstein Lived Here 75, italics mine.

52 For the distinction between "matters of fact" and "matters of concern" see Bruno Latour, "Why Has Critique Run Out of Steam? From Matters of Fact to Matters of Concern," Critical Inquiry 30.2 (2004). 
53 Even more ironically, the president of the Société française de Physique attended all of Einstein's conferences at the Collège de France. On those who accepted or rejected Einstein see Charles Nordmann, "Einstein à Paris," Revue des deux mondes.

54 Bulletin scientifique des etudiants de Paris, March 1923.

55 Jean Becquerel, "Préface," in La Relativité: Exposé dans formules des théories d'Einstein et réfutation des erreurs contenues dans les ouvrages les plus notoires (Paris: Etienne Chiron, 1923) vi.

56 André Metz, La Relativité: Exposé dans formules des théories d'Einstein et réfutation des erreurs contenues dans les ouvrages les plus notoires (Paris: Etienne Chiron, 1923).

57 André Metz, Temps, espace, relativité, vol. 2, Science et philosophie (Paris: Gabriel Beauchesne, 1928) 13.

58 Henri Gouhier, "Avant-Propos," in Mélanges.

59 Metz's response first appeared in the Revue de philosophie 31 (1924). In a letter to Einstein he explained its purpose: "L'article de la Revue de philosophie a pour but de refuter Bergson. ..." See Metz to Einstein, Bonn to Berlin, 30 April 1924, 4pp., Document No. 18 250, Folder 18.8. A. Metz, Paris(2), Box 7, EA. Bergson's published exchanges with Metz were reprinted in Gunter, ed., Bergson and the Evolution of Physics, pp. 135-90.

60 First published as "Les Temps fictifs et le temps réel," Revue de philosophie 24.3 (1924).

61 Bergson, "Durée et simultanéité" 232-33. "Physics could do a service to philosophy by abandoning certain ways of speaking that induce philosophy into error, and that risk confusing physicists themselves about the metaphysical significance of their views." Appendix III of "Durée et simultanéité" 237.

62 Bergson, "Durée et simultanéité" 64.

63 Bergson, "Les Temps fictifs et les temps reél" 1439.

64 "The meaning of my thoughts, as that of my book, has completely escaped him. There is nothing I can do." Henri Bergson, "Bergson à E. Peillaube," Revue de philosophie 24 (July 1924): 440. Reprinted in Bergson, Mélanges 1450.

65 Einstein to Metz, July 2, 1924, republished in Bergson and the Evolution of Physics, ed. Gunter, 190.

66 La Direction, "Réponse de Henri Bergson," Revue de philosophie 24 (July 1924). Metz informed Einstein of its publication: "Il est bien entendu que la lettre que je solicite de vous est destine à être inséré (sauf avis contraire de votre part) dans la Revue de Philosophie.-J'ai d'ailleurs fait bien souvent usage de vos lettres (qui m'ont servi à dissiper bien de erreurs) et j'espère que vous n'y voyez pas d'inconvénient." See Metz to Einstein, 23 November 1924, Bonn, 5pp. on p. 2, Document No. 18 253, Folder 18.8. A. Metz, Paris (5), Box 7, EA.

67 See Masriera Rubio, "La verdad sobre Einstein," 5 January 1925, Document No. 17 086, "El antirrelativismo psicológico," 7 January 1925, Document No. 17 086.1, "El estado actual de las doctrinas de Einstein," 25 October 1925, Document No. 17088 in Folder 3 of 3, Miguel Masriera (1) Scientific Correspondance File, Folders M-Misc. 1, Box 6, EA.

68 "Kurz: Bergson vergass, dass raumzeitlische Koinzidenz auch nach der Relativitätstheorie absoluten Character hat." Einstein to Masriera Rubio, Berlin, 7 October 1925, 2pp. on p. 1, Document No. 17087 in Folder 3 of 3, Miguel Masriera(2) Scientific Correspondance File, Folders M-Misc. 1, Box 6, EA. The letter was republished in translation in Masriera Rubio, "De Einstein a mis lectores . ..," La Vanguardia, November 1925, 3pp., see Document No. 17 089, in 
Folder 3 of 3, Miguel Masriera(3) Scientific Correspondance File, Folders M-Misc. 1, Box 6, EA.

69 Bergson to Lorentz, Paris, November 1924 in Bergson, Correspondances 22.

70 One of the most important associations of this kind was the International Association of Academies (IAA) founded in 1899 and counting 22 members by 1914. After the treaty of Versailles the International Research Council (IRC) was set up. The International Council for Science (ICSU) was founded in 1931. For the history of the IAA see Schroeder-Gudehus, "Les Congrès Scientifiques et la Politique de Coopération Internationale des Académies de Science," Relations Internationales 62 (1990). For the IRC see Kevles, "Into Hostile Political Camps': The Reorganization of International Science in World War I." For the ICSU see H. Spencer Jones, "The Early History of the ICSU 1919-1946," ICSU Review 2 (1960).

71 See Peter Galison, "Einstein's Clock: The Place of Time," Critical Inquiry 26 (Winter 2000); and Peter Galison, Einstein's Clocks, Poincaré's Maps (2003).

72 Gilbert Murray to Einstein, Oxford, 10 July 1922, 2pp. on p. 1-2, Document No. 34 777, Folder 9, Folders 34.9-11 League of Nations, Box 14, EA.

73 Murray to Einstein, Oxford, 16 May 1924, Document No. 34 807, Folder 9, Folders 34.9-11 League of Nations, Box 14, EA.

74 For his re-invitation, see Eric Drummond (Secretary General to the League of Nations) to Einstein, Geneva, 21 June 1924, 1p. Document No. 34 805, Folder 9 , Folders 34.9-11 League of Nations, Box 14, EA.

75 Bergson, "Commission Internationale de Coopération Intellectuelle: Ouverture de la session," July 24, 1924, Archives de l’Unesco. Reprinted in Bergson, Mélanges 1454-55.

76 Isaak Benrubi, Souvenirs sur Henri Bergson (Neuchâtel: Delachaux \& Niestlé, 1942).

77 Ibid. 107-08; see also Genovesi, "Henry Bergson: Lettere a Einstein" 8-9; and Mossé-Bastide, Bergson éducateur 126.

78 The original is: "Es wird Gras darüber wachsen, und dann wird man mit mehr Objectivität darüber urteilen." Cited in Benrubi, Souvenirs sur Henri Bergson 108; and Mossé-Bastide, Bergson éducateur 126.

79 See Bergson to Einstein, St. Cergue (Switzerland), 15 July 1925, Document No. 34 814, Folder 9, Folders 34.9-11 League of Nations, Box 14, EA. Published in Bergson, Correspondances 1161-62.

80 Mossé-Bastide, Bergson éducateur 145.

81 Albert Einstein, "How I Became a Zionist," in The Collected Papers of Albert Einstein (Princeton, N.J.: Princeton UP, 2002). Originally published as Albert Einstein, "How I Became a Zionist," Jüdische Rundschau (1921).

82 Bergson to Einstein, February 5, 1925, in Bergson, Correspondances 1147. Catalogued as Document No. 34.26.00, EA.

83 Renoliet, L'UNESCO oubliée: La Société des Nations et la coopération intellectuelle (19191946) 72.

84 Jean-Marc Lévy-Leblond, "Le boulet d'Einstein et les boulettes de Bergson," Annales Bergsoniennes 3 (forthcoming 2006).

85 Paul Valéry to Bergson, Nice, June 25, 1934, in Bergson, Mélanges 1511-12.

86 Bergson, Les Deux sources 310.

87 Renoliet, L'UNESCO oubliée: La Société des Nations et la coopération intellectuelle (19191946) 93. 
88 Ibid. 7.

89 Murray to Einstein, June 21, 1932, 2pp. on p. 2, Document No. 34 892, Folder 10, Folders 34.9-11 League of Nations, Box 14, EA.

90 "In 1940-44 all my things were kept by the Nazis and disappeared from my flat in Strasbourg. I succeeded to go to England (with my sons) to join the Free French Forces. . . . I never found again the letters received from Einstein (and from Eddington, Becquerel, Meyerson, etc.).” Metz to Helene Dukas, Antony (Seine) to Princeton, January 10, 1960, Document No. 18 269, Folder 18.8. A. Metz, Box 7, EA. For her response and his interest in recovering Einstein's letters with "his opinion about Bergson" see their correspondence from Antony (Seine) to Princeton, Documents No. 18270 and 18 271, Folder 18.8. A. Metz, Box 7, EA.

91 The prize was not limited to fiction. I want to thank Mitchell Ash for this observation.

92 Bergson did not attend the Nobel Banquet. He sent a letter which was read by the French Minister, Arman Bernard. See Bergson, "Banquet Speech," in Nobel Lectures, Literature 1901-1967 (Amsterdam: Elsevier, 1969).

93 Per Hallström, President of the Nobel Committee of the Swedish Academy, "Presentation Speech" (December 10, 1928), in Nobel Lectures, Literature 19011967.

94 Paul Arthur Schilpp, ed., Albert Einstein, Philosopher-Scientist, vol. 7, Library of Living Philosophers (Evanston: Open Court, 1949).

\section{WORKS CITED}

Agamben, Giorgio. "Mysterium disiunctionis," in The Open: Man and Animal. Ed. Werner Hamacher. Stanford: Stanford UP, 2004.

Becquerel, Jean. "Préface," in La Relativité: Exposé dans formules des théories d'Einstein et réfutation des erreurs contenues dans les ouvrages les plus notoires, v-xviii. Paris: Etienne Chiron, 1923.

Benrubi, Isaak. Souvenirs sur Henri Bergson. Neuchâtel: Delachaux \& Niestlé, 1942.

Bergson, Henri. "Bergson à E. Peillaube," in Revue de philosophie 24 (July 1924): 440.

- Correspondances. Ed. André Robinet. Paris: Presses Universitaires de France, 2002.

. "Discussion avec Einstein," in Mélanges, 1340-47. Paris: Presses Universitaires de France, 1972.

"Durée et simultanéité: a propos de la théorie d'Einstein" (1922), in Mélanges, $58-244$.

—. Les Deux sources de la morale at de la religion. Paris: F. Alcan, 1932.

—. Ecrits et paroles. Paris: Presses Universitaires de France, 1959.

"La Pensée et le mouvant" (1934) in Oeuvres. Paris: Presses Universitaires de France, 1991: 1251-482.

—. "Les Temps fictifs et le temps réel" (1924), in Mélanges, 1432-49.

—. "Les Temps fictifs et le temps réel” (1924), in Revue de philosophie 24.3: 241-60.

"Préface to Durée et Simultanéité" (1923), in Mélanges, 59-61.

Besaude-Vincent, Bernadette. "When a Physicist turns on Philosophy: Paul Langevin (1911-39)," in Journal of the History of Ideas 49.2 (1988): 319-38. 
Biezunski, Michel. Einstein à Paris: Le Temps n'est plus . . . Vincennes: Presses Universitaires de Vincennes, 1991.

The Born-Einstein Letters: Friendship, Politics and Physics in Uncertain Times. New York: Macmillan, 2005.

Canales, Jimena. "Exit the Frog, Enter the Human: Physiology and Experimental Psychology in Nineteenth-Century Astronomy," in British Journal for the History of Science 34 (June 2001): 173-97.

_. "Photogenic Venus: The 'Cinematographic Turn' and Its Alternatives in Nineteenth-Century France," in Isis 93 (2002): 585-613.

Čapek, Milič. "What is Living and What is Dead in the Bergsonian Critique of Relativity," in The New Aspects of Time. Ed. Robert S. Cohen. Dordrecht: Kluwer, 1991. 296-323.

"Commission Internationale de Coopération Intellectuelle" (1922), in Mélanges, 1352 53.

Einstein, Albert. "How I Became a Zionist," in The Collected Papers of Albert Einstein. Princeton: Princeton UP, 2002. 234-37

—. "How I Became a Zionist" (1921), Jüdische Rundschau: 351-52.

- Ideas and Opinions. New York: Three Rivers, 1984.

—. Letters to Solovine. New York: Philosophical Library, 1987.

—. Mein Weltbild. Amsterdam: Querido, 1934.

Forman, Paul. "Scientific Internationalism and the Weimar Physicists: The Ideology and its Manipulation after World War I," in Isis 64 (1973): 151-80.

Galison, Peter. "Einstein's Clock: The Place of Time," in Critical Inquiry 26 (Winter 2000): 355-89.

—. Einstein's Clocks, Poincaré's Maps. London: Norton, 2003.

Genovesi, Angelo. "Henry Bergson: Lettere a Einstein," in Filosofia 49.1 (1998): 3-39.

Goenner, Hubert. Einstein in Berlin, 1914-1933. Munich: C. H. Beck, 2005.

Gouhier, Henri. "Avant-Propos," in Mélanges, vii-xxiii.

Gunter, P.A.Y., ed. Bergson and the Evolution of Physics. Knoxville: U Tennessee P, 1969.

Jones, H. Spencer. "The Early History of the ICSU 1919-1946," in ICSU Review 2 (1960): $169-87$.

Kevles, Daniel J. "'Into Hostile Political Camps': The Reorganization of International Science in World War I," in Isis 62 (1971): 47-60.

La Direction. "Réponse de Henri Bergson," in Revue de philosophie 24 (July 1924): 440.

Lalande, André. "Philosophy in France, 1922-1923," in The Philosophical Review 33.6 (1924): 535-59.

Latour, Bruno. Politics of Nature: How to Bring the Sciences into Democracy. Trans. Catherine Porter. Cambridge: Harvard UP, 2004.

—. We Have Never Been Modern. Cambridge: Harvard UP, 1991.

"Why Has Critique Run Out of Steam? From Matters of Fact to Matters of Concern," in Critical Inquiry 30.2 (2004): 225-48.

Lévy-Leblond, Jean-Marc. "Le boulet d'Einstein et les boulettes de Bergson," in Annales Bergsoniennes. Ed. Frédéric Worms and Paul-Antoine Miquel, forthcoming 2006.

Lynch, Michael. "Technical Work and Critical Inquiry: Investigations in a Scientific Laboratory," in Social Studies of Science 12 (1982): 499-533. 
Metz, André. La Relativité: Exposé dans formules des théories d'Einstein et réfutation des erreurs contenues dans les ouvrages les plus notoires. Paris: Etienne Chiron, 1923.

Temps, espace, relativité. Vol. 2, Science et philosophie. Paris: Gabriel Beauchesne, 1928.

Mossé-Bastide, Rose-Marie. Bergson éducateur. Paris: Presses Universitaires de France, 1955.

Nathan, Otto, and Heinz Norden, eds. Einstein on Peace. New York: Avenel, 1960.

Nordmann, Charles. "Einstein à Paris," in Revue des deux mondes: 926-37.

Pais, Abraham. Einstein Lived Here. Oxford: Clarendon Press, 1994.

Renoliet, Jean-Jacques. L'UNESCO oubliée: La Société des Nations et la coopération intellectuelle (1919-1946). Paris: Publications de la Sorbonne, 1999.

Schaffer, Simon. "Astronomers Mark Time: Discipline and the Personal Equation," in Science in Context 2 (1988): 115-45.

Schilpp, Paul Arthur, ed. Albert Einstein, Philospher-Scientist. Vol. 7, Library of Living Philosophers. Evanston: Open Court, 1949.

Schroeder-Gudehus, Brigitte. "Les Congrès Scientifiques et la Politique de Coopération Internationale des Académies de Science," in Relations internationales 62 (1990): 135-48.

Seelig, Carl, ed. Albert Einstein: eine dokumentarische Biographie. Zürich: Europa Verlag, 1954.

Sokal, Alan, and Jean Bricmont. "Un regard sur l'histoire des rapports entre science et philosophie: Bergson et ses successeurs," in Impostures intellectuelles. Paris: Odile Jacob, 1997. 165-84

Soulez, Philippe. Bergson politique. Paris: Presses Universitaires de France, 1989.

Stanley, Matthew. "An Expedition to Heal the Wounds of War: 1919 Eclipse and Eddington as Quaker Adventurer," in Isis 94 (2003): 57-89.

Worms, Frédéric. "Entre critique et métaphysique: la science chez Bergson et Brunschvicg," in Les Philosophes et la science, edited by Pierre Wagner: Gallimard, 2002. 